\title{
Analysis of the Influence of Economic Growth, Government Expenditure and Investment on the Poverty in North Sumatra Province
}

\author{
Marita $^{1}$, Weni Hawariyuni ${ }^{2}$, Irsad Lubis $^{3}$ \\ ${ }^{1}$ Master of Economic Students, ${ }^{2,3}$ Lecturer of Master Economic \\ ${ }^{1,2,3}$ Faculty of Economics and Business, Universitas Sumatera Utara, Indonesia.
}

Corresponding Author: Marita

\begin{abstract}
Poverty is one of the problems that become the center of attention in any country including Indonesia, especially North Sumatra Province. In poverty alleviation, the government is required to supervise supporting policies that can alleviate the poverty level. Factors that can alleviate poverty are economic growth, government expenditure, and investments made. The purpose of this study is to find out and analyze the influence of economic growth, government expenditure, and investment on poverty levels in North Sumatra Province. This type of research is ex post facto and associative. The type of data used is quantitative in the form of secondary data. The population of this study is variable data in districts/cities in North Sumatra Province, namely as many as 33 districts/cities during 2014-2018 and sample withdrawal used is cluster sampling so that the sample as many as 165 observations. The data analysis method used is to use multiple linear regressions using Eviews10.0 software. The results showed economic growth, government expenditure and simultaneous investment negatively and significantly affected the poverty rate in North Sumatra Province with a coefficient of determination (R2) of 0.9938 or $99.38 \%$. Partial economic growth has a negative and significant effect on the poverty rate in North Sumatra Province while government expenditure and investment have an insignificant negative effect on poverty in North Sumatra Province.
\end{abstract}

Keywords: Economic Growth, Government Expenditure, Investment, Poverty Level.

\section{INTRODUCTION}

Poverty (low quality of life) is one of the problems faced by developing countries as faced by Indonesia today. In Indonesia, there are still many poor people marked by the number of people who still lack foodstuffs and the number of people who are still difficult to meet their basic needs, and the number of unemployed. The level of stability is also marked by Presidential Regulation No. 15 of 2010 on Acceleration of Poverty Alleviation. This indicates that poverty in Indonesia still needs to get serious attention from the government.

In RKP 2019, the government declared 5 (five) national priorities in poverty alleviation both at the central and regional levels. The five national priorities consist of: 1) human development through poverty reduction and improvement of basic services; 2) reduction of inequality between regions through strengthening connectivity and maritime affairs; 3) strengthening economic added value and job creation through agriculture, industry, tourism, and other productive services; 4) strengthening energy security, food, and water resources; and 5) national security stability and electoral success. Other programs include the expansion of cashless social assistance that must be ensured to run on time, directing cashless food assistance to improve people's food consumption patterns, and cash-for-work programs for 
underprivileged people. Cash-intensive work aims to increase incomes, create temporary jobs, lower stunting rates, and reduce the poverty of villages experiencing disasters, post-conflict, and food insecurity.

North Sumatra Province is one of the policies that has been carried out by the government is to provide village funds. This policy at the same time integrates and optimizes all budget allocation schemes from the Government to villages that have been around. Village funds are state budget funds intended for villages transferred through district or municipal budgets and prioritized for the implementation of village community development and empowerment. The purpose of village funds is to improve public services in the village, alleviate poverty, advance the village economy, overcome development gaps between villages and strengthen the village community as the subject of development. Following one of the village funding programs is to alleviate poverty, a very appropriate and sustainable policy is needed in achieving it.

The following graphs are presented that describe the amount of poverty in North Sumatra Province and the targets set by the government:

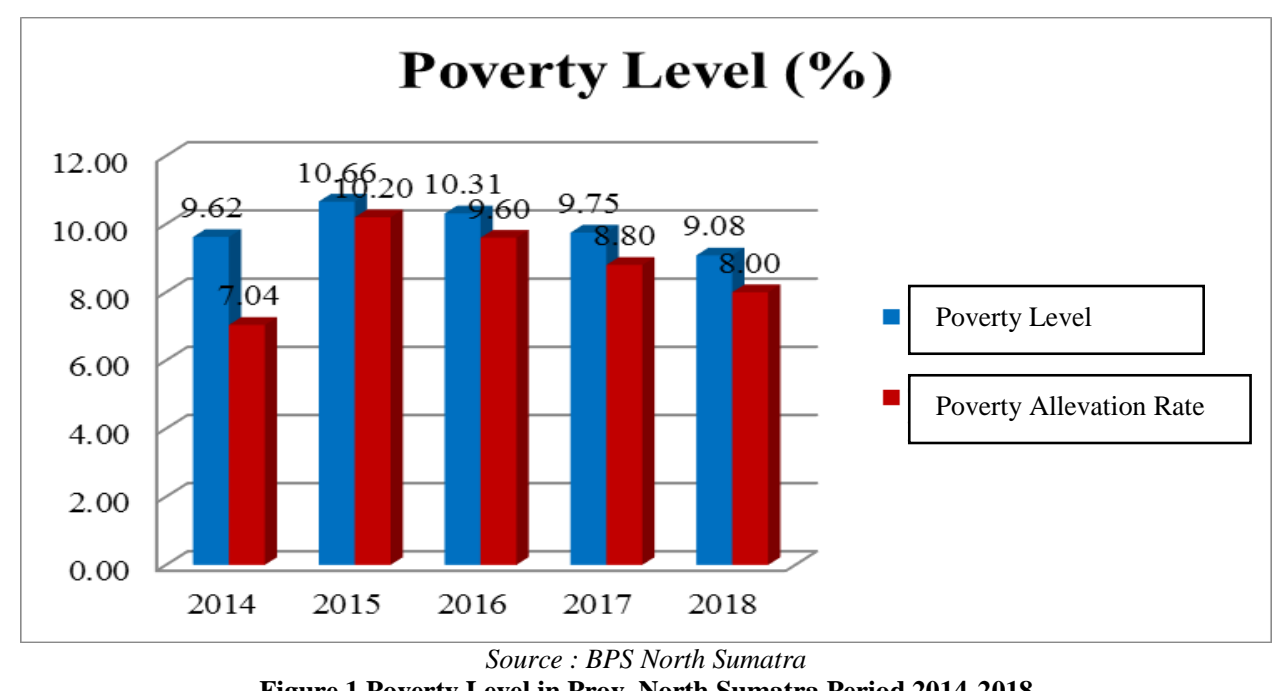

Figure 1 Poverty Level in Prov. North Sumatra Period 2014-2018

Figure 1 shows that the amount of poverty changed from 2014 to 2018 . In 2015, the highest percentage reached 10.66 percent still not in line with the government's target of 10.20 percent. One of the reasons for the high percentage of the poor is because of the low percentage of economic growth in 2015 around 5.10 percent. In 2016, the percentage of poor people decreased by 0.35 percent to 10.31 percent but still did not reach the government's target of 9.60 percent. In 2017, the percentage of poor people decreased back to 9.75 percent but still did not meet the government's target of 8.80 percent. And in 2018, there was a decrease of 0.66 to 9.08 percent but still did not meet the government's target of 8.00 percent.
Figure 2 shows GDP in North Sumatra province which increases every year. The increase in GDP tends to lead to an increase in economic growth every year. The data also shows that the increase of GDP every year which is a projection of economic growth has not been able to alleviate poverty in North Sumatra Province following the target set by the government. The results of an empirical study conducted by Mills and Pernia (1993) by crossCountry analysis method show that poverty in a country is lower if economic growth in the previous year is high the rate of GDP growth is faster down the poverty rate (Tambunan, 2011). 
Marita et.al. Analysis of the influence of economic growth, government expenditure and investment on the poverty in North Sumatra Province.

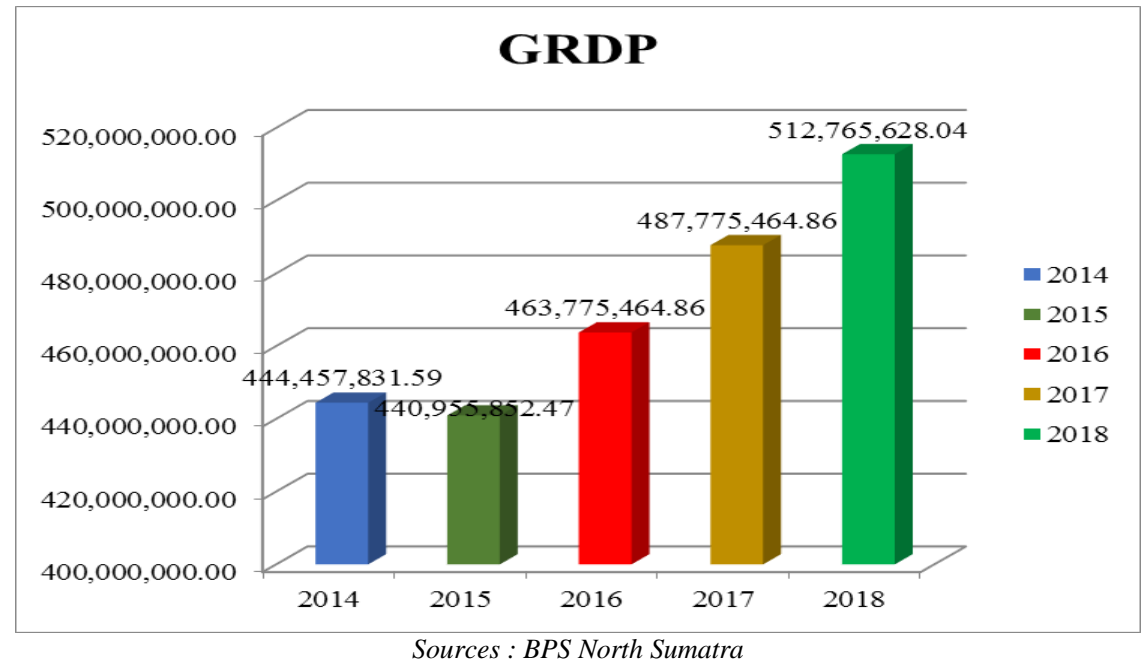

Figure 2 Gross Regional Domestic Product of North Sumatra Period 2014-2018

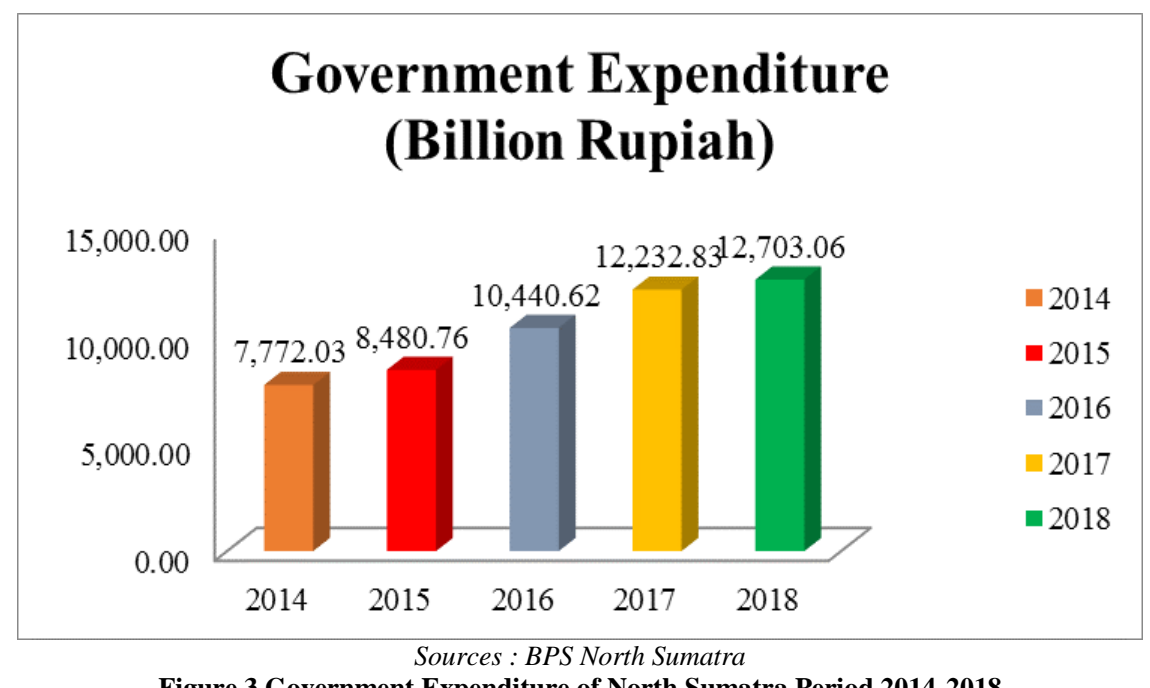

Figure 3 Government Expenditure of North Sumatra Period 2014-2018

Figure 3 shows that government expenditure tends to increase every year. This increase in government expenditure is expected to encourage poverty alleviation. But if it is linked to the poverty level in North Sumatra Province that does not meet the target set by the government. This indicates that government expenditure has not been effective or not on target in poverty alleviation programs in North Sumatra Province. Government expenditure also not only looks at the amount but also sees the accuracy of the target in government expenditure (Osinubi, 2005).

From diagram 4, it can be obtained that investment in North Sumatra Province tends to be volatile. The success of development in an area besides determined by economic growth is also influenced by the amount of investment. Investment can be a starting point for the success and sustainability of future development because it can absorb the workforce, to open new employment opportunities for the community that in turn will have an impact on the increase in people's income that can ultimately reduce the level of poverty.

The increase in GDP followed by increased government distribution and volatile investment value was not necessarily able to reduce the poverty level if not managed optimally or if there is no government alignment with the poor. Based on this background, the author is interested in conducting a study entitled "Analysis of the Influence of Economic Growth, Government Expenditure, and Investment on The Poverty in North Sumatra Province". 


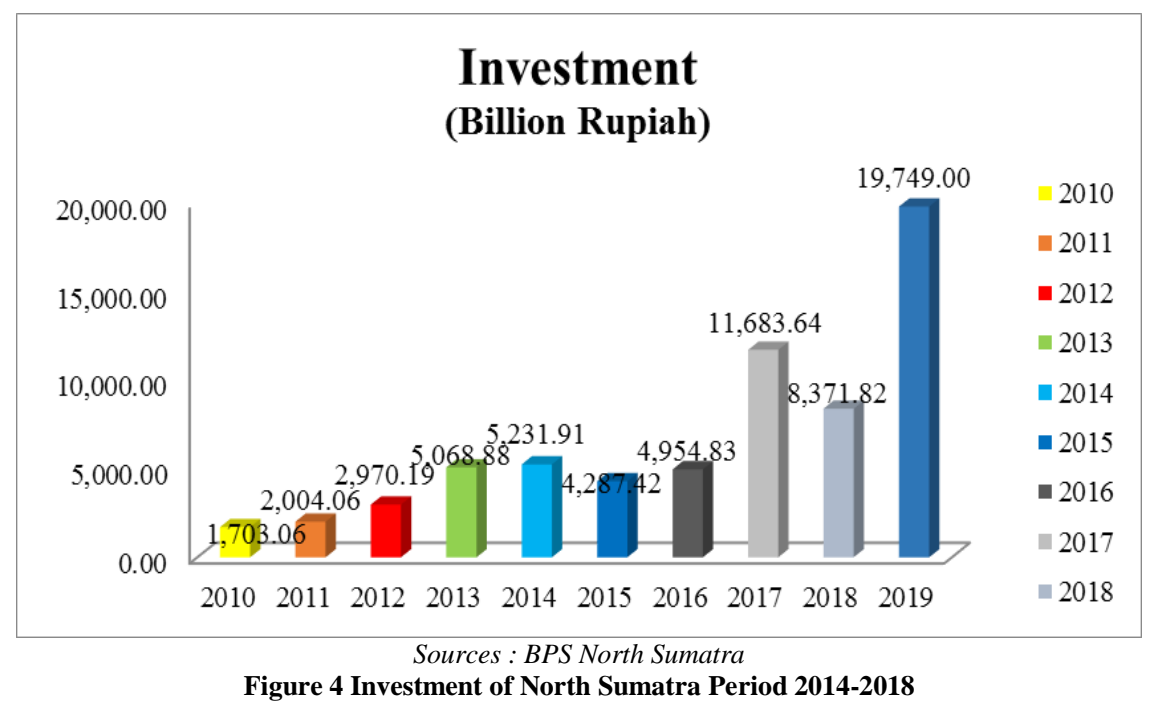

\section{LITERATURE REVIEW Poverty Level}

Poverty is a problem faced by almost all countries in the world, especially developing countries such as Indonesia. Poverty trends in Indonesia can usually be seen in the Indonesian Central Bureau of Statistics. According to the Central Bureau of Statistics (2021), that poverty is seen as the inability of the economic side to meet the basic needs of food and not food as measured in terms of expenditure, whereas according to Kuncoro (2010:280-281), poverty is defined as the inability to meet the minimum standard of living, where poverty measurement is based on consumption. From the previous understanding, it can be interpreted that poverty is generally seen in terms of the ability to meet the minimum standard of living.

\section{Gross Domestic Product}

According to Sukirno (2012:29), economic growth is the development of an economic activity that prevails over time and causes real national income to grow while Subandi (2011:15) defines economic growth as an increase in GDP/GNP regardless of whether the increase is greater or smaller than population growth, or whether there is a change in economic structure or not. It can be concluded that economic growth is the process of changing the economic condition of a country continuously towards a better state during a certain period. Economic growth can also be interpreted as the process of increasing the production capacity of an economy that is realized in the form of an increase in national income.

According to (Todaro and Smith, 2011) there is currently a new view on the importance of quality economic growth, namely in addition to encouraging economic growth to remain high also noted the quality of economic growth. The discussion showed that some countries managed to achieve high growth, but the level of inequality and poverty did not continue to decline. While the negative impacts of inequality include economic inefficiency, weakening social stability and solidarity, and high inequality is generally seen as unfair to the welfare of society (Todaro, 2004). Therefore, tackling poverty inequality and community welfare is required by several government policies to increase the growth of the Indonesian economy, especially in North Sumatra Province.

\section{Government Expenditure}

Government expenditure is usually interpreted as funds spent by the government in running the wheels of government both in the region and in the center. Government expenditures according to Sukirno (2012) are as follows: "Government expenditures are the entire expenditures made that include consumption 
and investment while according to Susanti (2000) government expenditures are one aspect of the use of economic resources controlled and owned by the public through tax payments. Government expenditure reflects policies that have been taken by the government. The better government expenditure is allocated, it will also be able to alleviate poverty. By looking at the allocation of government expenditure can also reflect the government's impartiality towards the small people.

\section{Investment}

To help the poverty level, several measures need to be implemented to increase economic growth, one of which is to make investments. According to Sukirno (2012) investment activities allow society to continuously increase economic activities and employment opportunities, increase national income and improve the level of prosperity of the community. Everything that is done to improve the ability to create and add value to the usefulness of life is an investment, so the investment is not only in physical form, but also non-physical especially the improvement of the quality of human resources (Wahab, 2012). The function of the investment will be able to increase economic growth to alleviate poverty because the investment provided by the government can be directly felt by the community. With optimal investment, it will be able to prosper the lives of small communities.

\section{Framework}

To facilitate the research activities to be conducted and to clarify the flow of thought in the research to be conducted and to clarify the flow of thought in this research, namely:

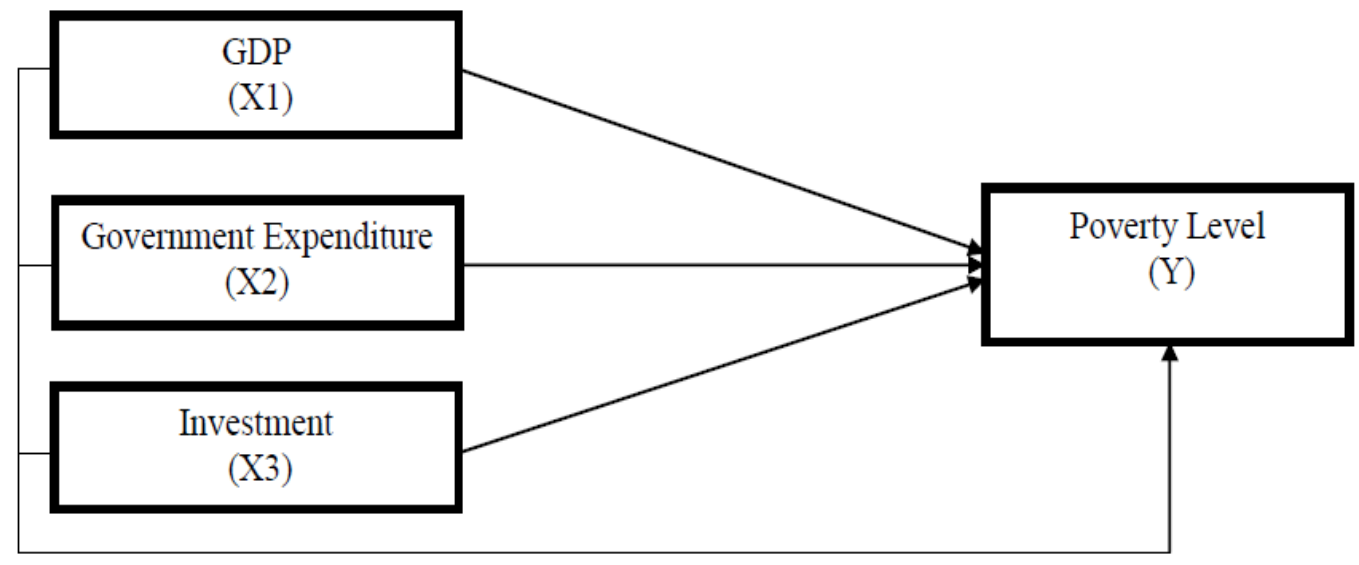

\section{RESEARCH METHODS}

The type of data in this study is quantitative data. While the data source in this study is secondary data from the publication of the Central Statistics Agency (BPS) and the Ministry of Finance collected is including data on government expenditures, investment, economic growth, and poverty rates directly or indirectly in the District / City in North Sumatra Province. This study uses a data panel (pooled data) that combines time series and cross-section data.
The population in this study is data on government expenditures, investment, economic growth, and poverty rates in 33 regencies/cities of North Sumatra Province. The sampling technique used is cluster sampling. By using cluster sampling, this research sample is 5 years of data that is from 2014 to 2018 in 33 districts/cities of North Sumatra province so that the number of observations of this study is 5 Years x 33 districts/cities $=165$ observations. 
Marita et.al. Analysis of the influence of economic growth, government expenditure and investment on the poverty in North Sumatra Province.

\section{RESULT AND DISCUSSION Normality Test}

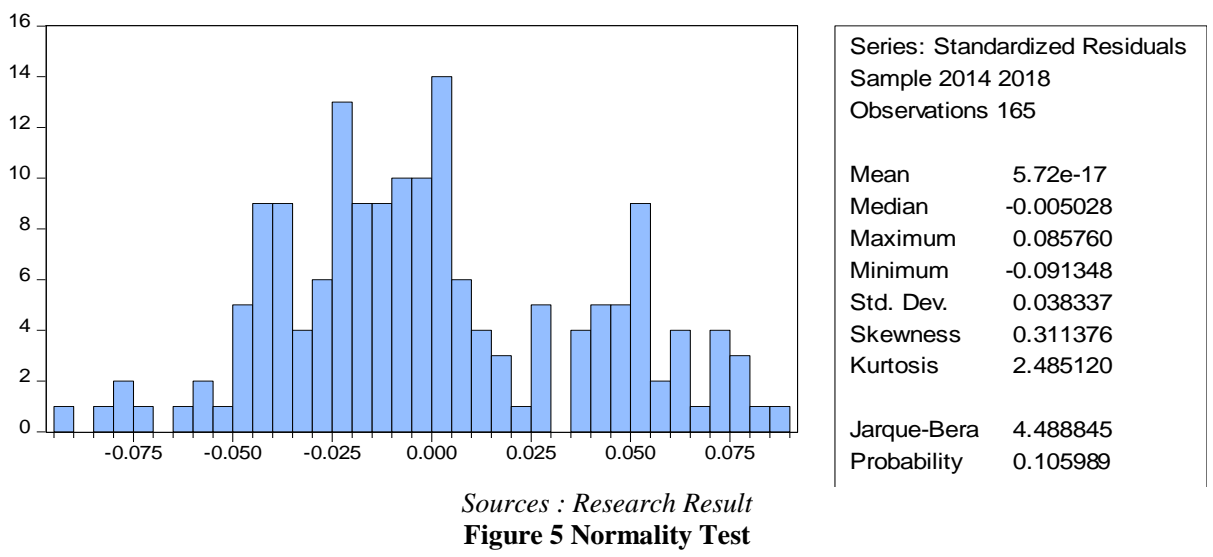

The picture above shows the normality test of the data using a histogram with probability results $\alpha(0.05)$ then it can be concluded that the data in this study are distributed normally.

\section{Multicollinearity Test}

\begin{tabular}{|l|l|l|l|l|}
\multicolumn{2}{l}{ Table 1. Multicolerity Test Result } \\
\begin{tabular}{|l|l|l|l|l|}
\hline & Poverty & GDP & Government Expenditure & Investment \\
\hline Poverty Level & 1 & 0.7961 & 0.6251 & 0.7497 \\
\hline GDP & 0.7961 & 1 & 0.6456 & 0.7811 \\
\hline Government Expenditure & 0.6251 & 0.6456 & 1 & 0.4493 \\
\hline Investment & 0.7497 & 0.7811 & 0.4493 & 1 \\
\hline
\end{tabular} \\
\hline
\end{tabular}

Based on the test results in the table above it is obtained that none of the correlations on each independent variable are greater than 0.8 . This means that the regression model does not experience multicollinearity problems.

\section{Autocorrelation Test}

The figures showed that the value of Durbin Watson Stat is between dU and 4-
$\mathrm{dU}$ and also between $\mathrm{dL}$ and 4-dL, it can be concluded that the data is free from autocorrelation problems.

Table 2. Autocorrelation Test Result

\begin{tabular}{|l|l|l|}
\hline Subject & Result \\
\hline \multirow{3}{*}{ Durbin Watson table } & $\mathrm{dU}$ & 1,7085 \\
\cline { 2 - 3 } & $\mathrm{dL}$ & 1,7825 \\
\cline { 2 - 3 } & $4-\mathrm{dU}$ & 2,2175 \\
\cline { 2 - 3 } & $4-\mathrm{dL}$ & 2,2925 \\
\hline Durbin-Watson stat & 1,8142 \\
\hline
\end{tabular}

Sources : Research Result

\section{Heteroskedasticity Test}

Table 3. Heteroskedasticity Test

\begin{tabular}{|l|l|l|l|l|}
\hline Dependent Variable: RESABS & & \\
\hline Method: Panel Least Squares & & \\
\hline Variable & Coefficient & Std. Error & t-Statistic & Prob. \\
\hline C & 7033.061 & 3095.594 & 2.271958 & 0.0247 \\
\hline PERTUMBUHAN_EKONOMI & $-3.67 \mathrm{E}-05$ & $3.83 \mathrm{E}-05$ & -0.858291 & 0.3497 \\
\hline PENGELUARAN_PEMERINTAH & -0.007592 & 0.005958 & -1.374291 & 0.2249 \\
\hline INVESTASI & $5.13 \mathrm{E}-05$ & $4.61 \mathrm{E}-05$ & 1.113068 & 0.2677 \\
\hline
\end{tabular}

Based on the results of glacier tests contained in the table above that is seen heteroskedasticity shows that each variable has a probability above the value of $\alpha(0.05)$ then it can be concluded that the data is free from the problem of heteroskedasticity. 
Marita et.al. Analysis of the influence of economic growth, government expenditure and investment on the poverty in North Sumatra Province.

\section{Panel Data Estimate}

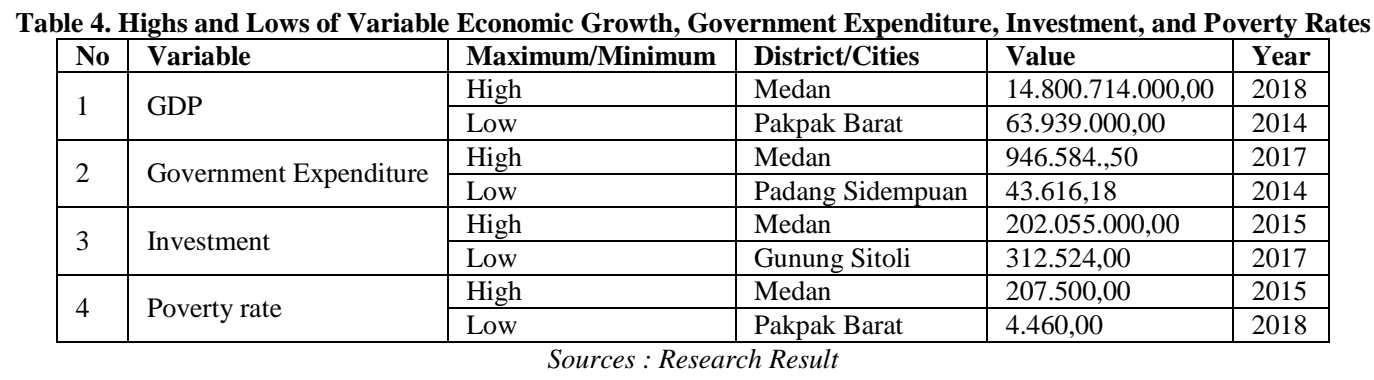

From the table above, it can be seen that the highest value for all variables is still dominated by Medan while the lowest value for growth variables and poverty level is in West Pakpak Regency, for the lowest value of government expenditure is in Padang Sidempuan Regency and for the lowest value of investment income is in Gunung Sitoli Regency.

\section{Determination of Estimated Models \\ Between Common Effect Model (CEM) and Fixed Effect Model (FEM) with Chow Test \\ In choosing whether the model} estimates a common effect model or fixedeffect model to form multiple linear regression models, they can be used chow test with the following results.

Table 5. Chow Test

\begin{tabular}{|l|l|l|l|}
\hline \multicolumn{3}{|l|}{ Redundant Fixed Effects Tests } & \\
\hline Test cross-section fixed effects & \\
\hline Effects Test & Statistic & d.f. & Prob. \\
\hline Cross-section F & 150.716778 & $(32,129)$ & 0.0000 \\
\hline Cross-section Chi-square & 601.874075 & 32 & 0.0000 \\
\hline \multicolumn{3}{|l|}{ Sources : Research Result } \\
\hline
\end{tabular}

The table above shows the chow test result where the cross-section chi-square probability value is 0.000 . With these results, the regression test recommended by the chow test is to use a fixed-effect model and common effect model testing is not done.

\section{Fixed Effect Model (FEM) and Random Effect Model (REM) with Housman Test}

In choosing whether the fixed effect model estimation model or random effect model to form multiple linear regression models, then it can be used Hausman test with the following results.

Table 6. Housman Test

\begin{tabular}{|l|l|l|l|}
\hline Correlated Random Effects - Hausman Test & \\
\hline Test cross-section random effects & Phi-Sq. \\
\hline Test Summary & $\begin{array}{l}\text { Chi-Sq. } \\
\text { Statistic }\end{array}$ & Prob. \\
\hline $\begin{array}{l}\text { Cross-section } \\
\text { random }\end{array}$ & 109.573667 & 3 & 0.0000 \\
\hline \multicolumn{3}{|c|}{ Sources : Research Result } \\
\hline
\end{tabular}

The table above shows the Housman test result where the random cross-section probability value is 0.000 . With these results, the regression test recommended by the Housman test is to use a fixed-effect model and random effect model testing is not done. Because the results of the chow test and Housman test that have been determined and decided the same result is using fixed effect model estimation model, there is no need to do a Lagrange multiplier test.

\section{Hypothesis Test}

Table 7. Statistic Result

\begin{tabular}{|c|c|c|c|c|}
\hline \multicolumn{5}{|c|}{ Dependent Variable: Poverty } \\
\hline \multicolumn{3}{|c|}{ Method: Panel Least Squares } & \multirow[b]{2}{*}{ t-Statistic } & \multirow[b]{2}{*}{ Prob. } \\
\hline Variable & Coefficient & Std. Error & & \\
\hline $\mathrm{C}$ & 50656.54 & 2573.276 & 19.68562 & 0.0000 \\
\hline GDP & $-3.50 \mathrm{E}-06$ & $1.07 \mathrm{E}-06$ & -3.252941 & 0.0015 \\
\hline Government Expenditure & -0.007592 & 0.005958 & -1.274291 & 0.2049 \\
\hline \multirow[t]{2}{*}{ Investment } & $-3.67 \mathrm{E}-05$ & $3.83 \mathrm{E}-05$ & -0.958291 & 0.3397 \\
\hline & \multicolumn{2}{|c|}{ Effects Specification } & & \\
\hline \multicolumn{4}{|c|}{ Cross-section fixed (dummy variables) } & \\
\hline R-squared & 0.995164 & \multicolumn{2}{|c|}{ Mean dependent var } & 42782.48 \\
\hline
\end{tabular}


Marita et.al. Analysis of the influence of economic growth, government expenditure and investment on the poverty in North Sumatra Province.

\begin{tabular}{|l|l|l|l|}
\hline \multicolumn{5}{|c|}{ Table 7 Continued.... } \\
\hline Adjusted R-squared & 0.993851 & S.D. dependent var & 37301.39 \\
\hline S.E. of regression & 2924.909 & Akaike info criterion & 18.99014 \\
\hline Sum squared resid & $1.10 \mathrm{E}+09$ & Schwarz criterion & 19.66781 \\
\hline Log likelihood & -1530.687 & Hannan-Quinn criter. & 19.26523 \\
\hline F-statistic & 758.3953 & Durbin-Watson stat & 1.814250 \\
\hline Prob(F-statistic) & 0.000000 & & \\
\hline \multicolumn{5}{|l}{ Sources : Research Result } \\
\hline
\end{tabular}

Based on the results in the table above can be compiled multiple linear regression analysis equations in this study as follows:

$\mathrm{Y}=50,656.54-0.00000350 \mathrm{X} 1-$ $0.00759178 \mathrm{X} 2-0.00003672 \mathrm{X} 3+\mathrm{e}$ $\mathrm{Y}=50,656.54-0.00000350$ (Economic Growth) - $0.007592 \quad$ (Government Expenditure) -0.0000367 (investment) $+\mathrm{e}$

From the equation of multiple linear regression analysis, it can be explained as follows:

1. The constant regression value of $50,656.54$ indicates that if economic growth, government expenditure, and investment value $=0$ or do not change from the initial situation, then poverty will increase by $50,656.54$. The results obtained from the multiple linear regressions are mathematically calculated and can be applied using the assumption that there are variables of economic growth, government expenditure, and investment but in a fixed or unchanged state.

2. Coefficient of regression $\mathrm{X} 1$ for economic growth variable worth 0.00000350 means the influence of economic growth variable as opposed to the poverty level. The results show that economic growth influences reducing poverty in North Sumatra Province in 2014-2018.

3. Coefficient of regression $\mathrm{X} 2$ for government expenditure variable worth 0.007592 means the influence of government expenditure variable as opposed to the poverty level. The results show that government expenditure influences reducing poverty rates in North Sumatra Province in 2014-2018.
4. Coefficient of regression X3 for investment variables worth 0.0000367 means the influence of investment variables contrary to the poverty level. The results showed that investment influenced reducing poverty in North Sumatra Province in 2014-2018.

\section{Coefficient of Determination Analysis}

Based on the results known value of the coefficient of determination (Adjusted $\mathrm{R}$-squared) of. The value can be interpreted as economic growth, government expenditure, and investment can influence/explain the poverty rate simultaneously or together by $99.38 \%$, the remaining $0.62 \%$ is influenced by other factors.

\section{Simultaneous Influence Significance Test (Test F)}

The test aims to test the influence of free variables together or simultaneously on non-free variables. Based on the results known prob value. (F-statistics), i.e. 0.000 0.05 and Fhitung>Ftabel of $758.3953>$ 2.6604 , it can be concluded that all free variables, namely economic growth, government expenditure, and investment simultaneously have a significant effect on poverty level variables.

\section{Partial Influence Significance Test (t Test)}

Based on the table- 8 , it is known that variables of government expenditure and investment have a negative (respectively) negative but insignificant effect on the poverty rate (Prob. > 0.05), while economic growth negatively and significantly affects the poverty rate. 
Marita et.al. Analysis of the influence of economic growth, government expenditure and investment on the poverty in North Sumatra Province.

Table 8. Partial Influence Significance Test Results

\begin{tabular}{|l|l|l|l|l|l|}
\hline Variable & Prob. & Sig & tcalculate $\mathbf{1 , 9 7 4 7}$ & $\begin{array}{l}\mathbf{H}_{\mathbf{0}} \text { accept } \\
\mathbf{H}_{\mathbf{0}} \text { reject }\end{array}$ & Note \\
\hline GDP & 0.0015 & $\alpha=0.05$ & $-3,252$ & $\mathrm{H}_{0}$ reject & $\begin{array}{l}\text { Economic growth negatively and significantly } \\
\text { affects poverty rates (Prob }<0,05)\end{array}$ \\
\hline Government Expenditure & 0.2049 & $\alpha=0.05$ & -1.274 & $\mathrm{H}_{0}$ accept & $\begin{array}{l}\text { Government expenditure has insignificant } \\
\text { negative effect on poverty (Prob>0,05) }\end{array}$ \\
\hline Investment & 0.3397 & $\alpha=0.05$ & -0.958 & $\mathrm{H}_{0}$ accept & $\begin{array}{l}\text { Investment has an insignificant negative effect on } \\
\text { poverty levels (Prob }>0,05)\end{array}$ \\
\hline
\end{tabular}

\section{DISCUSSION}

Effect of Economic Growth, Government Expenditure and Simultaneous Investment on Poverty Level.

The hypothesis states that variables of economic growth, government expenditure, and investment simultaneously negatively and significantly affect poverty rates. From the statistical test results obtained a statistical value of 50,656.54 and a significance value of $0.000<0.05$. Based on the results of hypothesis testing is known simultaneous influence of economic growth variables, government expenditure and investment negatively and significantly affects poverty levels means that these test results reject the hypothesis.

The results of this study explain that poverty rates are jointly influenced by variables of economic growth, government expenditure, and investment. If seen the influence is very large if conducted testing together is $99.38 \%$ which means only $0.62 \%$ poverty rate is influenced by variables other than the variables of this study. In contrast to partial testing that showed only a few independent variables were able to affect poverty rates.

This result when compared to the partial test then it is clear that government expenditure and investment are not factors that make the economic growth rate increase but are influenced by other factors such as large employment. This research is in line with research conducted by Pateda (2017) which states that the tightness of the relationship between investment, economic growth, government expenditure as a free variable with the poverty rate as a bound variable is 0.794 or $79.4 \%$.

\section{The Effect of Economic Growth on Poverty Level.}

From the results of statistical tests obtained t-Statistics value of $-3,252$ and significance value of $0.0015<0.05$. This indicates that economic growth has a negative and significant effect on the level of poverty which means that if economic growth increases in North Sumatra Province will be able to suppress or alleviate poverty. This can mean that economic growth can be a factor that can be utilized or emphasized in poverty alleviation.

The results of this study are in line with previous researches, namely research (Ratih et al., 2017; Sunusi, 2014; Arshanti and Wirathi, 2015) who say that economic growth has a negative and significant effect on poverty rates. This research is not in line with research conducted by Pratama and Utama (2019) which said that economic growth has a positive and significant effect on poverty rates. This means that the economic growth of districts / cities in Balu Province has not been able to reduce the percentage of poverty. Previous research is very much different from this study because this study has a negative direction while the research conducted by primary and primary has a positive direction which means the increase in economic growth of districts / cities in Bali Province has an effect on increasing the percentage of poverty rate.

\section{The Effect of Government Expenditure on Poverty Levels.}

From the results of statistical tests obtained t-Statistics value of $-1,274$ and a significance value of $0.204>0.05$. This shows that government expenditure has an insignificant negative effect on the poverty level meaning that the higher the level of 
government expenditure, the lower the poverty level. The decline in question shows the insignificant value which means that government expenditure is not real in lowering the poverty rate in North Sumatra Province. This can mean that government expenditure does not target poverty alleviation or government expenditure does not focus on poverty alleviation.

This research is in line with research conducted by Pateda, et al (2017) which found that spending has an insignificant negative effect on poverty rates in Gorontalo caused by the government's lack of utilization of government expenditure in poverty alleviation. This study is not in line with research conducted by Barika (2013) which found that government expenditure has a negative and significant effect on poverty levels in Sumatra Province. This shows that during the research conducted by Barika, provinces in Sumatra other than North Sumatra Province utilized government expenditures, namely the allocation of capital expenditures and infrastructure development in alleviating poverty. This research is also not in line with research conducted by Sanusi (2014) which found government expenditure has a positive and insignificant effect on poverty rates in North Sulawesi.

\section{The Effect of Investment on Poverty Level.}

From the results of statistical tests obtained t-Statistics value of -0.958 and a significance value of $0.3397>0.05$. This suggests that investment has an insignificant negative effect on poverty rates. The results show that the higher the amount of investment into North Sumatra Province, the poverty level will decrease. In 2014-2018 investments into North Sumatra Province decreased but were not significant or unreal. This finding can be interpreted that the increase in investment every year that goes into North Sumatra Province is not real as a variable in poverty alleviation in 2014-2018. The result of this study is the effect of increasing investment in North Sumatra
Province in the period 2014-2018 is not able to significantly / significantly reduce the poverty level in North Sumatra Province. This is because the investment made by the government and private parties in North Sumatra Province still has not touched the poor people in each district/city.

The results of this study are supported by previous research, namely Mustamin and Nurwati (2008) which stated that there are significant results between investment and poverty allegedly caused by existing investments only made by the upper-middle class. The results of this study are not in line with several previous studies, namely Ratih (2017), Pateda (2017), and Arshanti (2015) which stated that investment has a negative and significant effect on poverty rates.

\section{CONCLUSION}

Based on the results of the study, this study concluded the following results:

1. Economic growth, government expenditures, and investments have a negative and significant effect together on the poverty level in North Sumatra Province.

2. Economic growth has a negative and significant effect on poverty rates in North Sumatra Province.

3. Government expenditures have an insignificant negative effect on poverty rates in North Sumatra Province.

4. Investment has an insignificant negative effect on poverty rates in North Sumatra Province.

\section{Acknowledgement: None}

\section{Conflict of Interest: None}

\section{Source of Funding: None}

\section{REFERENCES}

1. Arshanti, Kadek Novita., Wirathi, I G A P. 2015. Pengaruh Investasi Terhadap Pengentasan Kemiskinan Melalui Mediasi Pertumbuhan Ekonomi Provinsi Bali. EJurnal Ekonomi Pembangunan Universitas Udayana Vol. 4 No. 5: 513-524 
Marita et.al. Analysis of the influence of economic growth, government expenditure and investment on the poverty in North Sumatra Province.

2. Badan Pusat Statistik Sumatera Utara. 2021. sumut.bps.go.id. Diakses pada 1 Maret 2021.

3. Barika. 2013. Pengaruh Pertumbuhan Ekonomi, Pengeluaran Pemerintah, Pengangguran, dan Inflasi terhadap Tingkat Kemiskinan di Provinsi se Sumatera. Jurnal Ekonomi Dan Perencanaan Pembangunan Vol. 5 No. 1. ISSN: 1979-7338

4. Budhi, Made Kembar Sri. 2013. Analisis Faktor-faktor Yang Berpengaruh Terhadap Pengentasan Kemiskinan Di Bali: Analisis FEM Data Panel. Jurnal Ekonomi Kuantitatif Terapan. Vol. 6 No.1:1-70

5. Hera, Susanti. 2000. Keuangan Daerah di Indonesia. LPFE UI. Jakarta.

6. Herman, E. 2011. The Impact of Economic Growth Process on Employment in European Union Countries. The Romanian Economic Journal.Vol.24 No.42

7. Kuncoro, M. 2010. Masalah, Kebijakan, dan Politik. Ekonomika Pembangunan. Jakarta: Penerbit Erlangga.

8. Lubis, Pardamean. Afifudin, Sya'ad \& Mahalli, Kasyful. 2008. Analisis Faktorfaktor Yang Mempengaruhi Permintaan Investasi di Indonesia. Jurnal Ilmiah.Vol.3 No.2: 111-126.

9. Osinubi, T. S. 2005. Macroeconometric Analysis Of Growth, Unemployment and Poverty in Nigeria. Pakistan Economic and Social. Vol. 12 No.2:249-269.

10. Pateda, Yolanda., Masinambouw, Vecky A.J dan Rotinsulu, Tri Oldy. 2017. Pengaruh Investasi, Pertumbuhan Ekonomi Dan Pengeluaran Pemerintah Terhadap Tingkat Kemiskinan Di Gorontalo. Jurnal Pembangunan Ekonomi dan Keuangan Daerah. Vol. 18 No. 6: 1-17

11. Pratama, Nengah Rai Narka Suda dan Utama, Made Suyana. 2019. Pengaruh Pengeluaran Pemerintah Dan Investasi Terhadap Pertumbuhan Ekonomi Dan Tingkat Kemiskinan Di Kabupaten/Kota Provinsi Bali. E-Jurnal Ekonomi dan Bisnis Universitas Udayana Vol. 8 No. 7: 651-680

12. Nurwati, Nunung. 2008. Kemiskinan: Model Pengukuran, Permasalahan dan
Alternatif Kebijakan. Jurnal Kependudukan Padjadjaran. Vol.10 No.1:1-11

13. Ratih. Gusti Ayu Putu Ambara., Utama, Made Suyana dan Yasa, I Ntoman Mahaendra. 2017. Pengaruh Investasi, Pengeluaran Pemerintah, Tenaga Kerja Terhadap Produk Domestik Regional Bruto Dan Tingkat Kemiskinan Pada Wilayah Sarbagita Di Provinsi Bali. E-Jurnal Ekonomi dan Bisnis Universitas Udayana Vol. 6 No.1: 29-54

14. Subandi. 2011. Ekonomi Pembangunan. Bandung: Alfabeta

15. Sukirno,Sadono. 2012. Makroekonomi Teori Pengantar. Edisi Ketiga. Jakarta: Rajawali Pers.

16. Sunusi, Dewi Kurniawati. 2014. Analisis Pengaruh Jumlah Tenaga Kerja, Tingkat Pendidikan, Pengeluaran Pemerintah pada Pertumbuhan Ekonomi dampaknya terhadap Kemiskinan di Sulawesi Utara. Jurnal Berkala Ilmiah Efisiensi. Vol. 14 No. 2: 120-137

17. Tambunan, Tulus, T.H. 2011. Perekonomian Indonesia, Kajian Teoritis dan Analisis Empiris. Jakarta: Ghalia Indonesia.

18. Todaro, M.P, 2000. Economic Development. Six Edition. Harlow: Addison- Wesley.

19. Todaro, Michael P. 2004. Pembangunan Ekonomi di Dunia Ketiga. Edisi 7. Jakarta: Erlangga

20. Todaro, Michael P. dan Stephen C. Smith. 2011. Pembangunan Ekonomi. Edisi kesebelas. Jakarta: Erlangga.

21. Wahab Abdul, 2012. Pengantar Ekonomi Makro, Samata:Alauddin University Pers Arsyad, L. (2010). Ekonomi pembangunan. Yogyakarta: UPP STIM YKPN.

How to cite this article: Marita, Hawariyuni W, Lubis I. Analysis of the influence of economic growth, government expenditure and investment on the poverty in North Sumatra Province. International Journal of Research and Review. 2021; 8(5): 238-248. DOI: https://doi.org/10. 52403/ijrr.20210532 